\title{
Green, Social Bonds in the Context of the Pandemic
}

\author{
Aybika Imranovna Beksultanova ${ }^{1, *}$, Paizat Alievna Ibragimova ${ }^{2}$, Dzhamilja \\ Salikhovna Sarkarova ${ }^{2}$
}

\author{
${ }^{1}$ Chechen State University named after A.A. Kadyrov, Grozny, Russia \\ ${ }^{2}$ Dagestan State university, Makhachkala, Russia \\ *Corresponding author.Email: adamovaaybika@mail.ru
}

\begin{abstract}
Today, with the COVID-19 pandemic, the sustainable development agenda has come into focus from a new angle. Issues of inequalities as well as themes of transparency, of effective engagement of different stakeholders to overcome common global challenges, on the other hand, have become increasingly relevant. As the UN notes, the COVID-19 pandemic has served as an unprecedented wake-up call, exposing high levels of inequality in the world and highlighting precisely the issues that have informed the 2030 Agenda and the Paris Climate Agreement. The study is devoted to the analysis of green finance issuance in the Russian market. It reveals problematic issues in this area associated with the lack of a sufficiently wide practice of green bonds issuance in the Russian market and the so far weak regulatory framework.
\end{abstract}

Keywords: Sustainable development, pandemic, green bonds

\section{INTRODUCTION}

At the beginning of the second decade of the $21 \mathrm{st}$ century, the world economy found itself under the simultaneous blow of two crises: the coronavirus pandemic and the collapse of hydrocarbon prices, primarily crude oil [1].

Calls for green economic recovery plans are heard around the world, and experts concerns are echoed by international organizations (International Monetary Fund, World Bank) as well as leading economists, the world's largest companies and investors.

The UN believes that any positive effects in the context of the pandemic must translate into changes in production and consumption patterns towards cleaner and greener ones, as only long-term systemic changes will really change the trend of carbon dioxide accumulation in the atmosphere. Thus, the recovery phase represents a convenient opportunity to lay down such trends through investments in renewable energy, smart buildings, and clean public transport.

The Canadian International Institute for Sustainable Development conducted an analysis of economic stimulus measures adopted in Europe and Asia and identified 4 main areas that seem promising in the current context in terms of progress in implementing the
SDGs: buildings, transport, nature restoration and "clean" energy. [2]

The first green funds began to appear in the early 1990s-, but their greatest activity has been in the last decade. As of early 2019, there were about 23 climate funds operating around the world, ten of which were set up by the World Bank, six under the Global Environment Facility, three more under regional development banks, and the rest established by various UN and EU committees. These funds have a combined cap of \$30.4 billion, and have invested more than $\$ 19.4$ billion worldwide since 2003, -according to Climate Fund Update. India and Brazil have the largest commitments ( $6 \%$ each, or around $\$ 1.1-1.2$ billion). These funds have been investing in climate change adaptation and mitigation projects, as well as additional investments in conservation and deforestation initiatives.

There are not many specialized funds in Russia yet. For example, the Energy from Waste project, which is $46 \%$ funded by VEB.RF, it is planned that the First Environmental Fund, created in early 2018 by RTinvest and Rusnano with the participation of the JapaneseSwiss company Hitachi Zosen Inova, will participate. [3] 
The project includes the construction of four plants for thermal processing of MSW into energy in Moscow and one more in Kazan, which will reduce the volume of buried waste in the Moscow region by more than $25 \%$, and reduce it to zero in the capital of Tatarstan. Another player in the market of domestic green finance is the Wind Energy Development Fund. Recently it has signed loan agreements with Otkritie Bank to finance projects of wind farms with total capacity of $445 \mathrm{MW}$ in Astrakhan and Volgograd regions. Moreover, wind farms in Astrakhan region will start supplying capacity and energy as early as at the end of 2021, while the Volgograd wind farm is planned to be put into operation by the end of 2022. The loan is issued on the principles of project financing, and the repayment of the debt is linked to the proceeds of generating wind farms' capacity provision agreements. We do not expect foreign players from green funds to come to Russia in the next year or two. Geopolitical reasons also hold them back, but to a greater extent it is an underdeveloped legal environment and green market investment infrastructure. Most likely, on the horizon of two to three years, the government may take the initiative to form a specialized green fund (similar to China's), or allocate certain mandates for such funding to existing public and quasi-public broad-based investment funds. There is a possibility that several private players may emerge in the market as part of the greening strategy, but they are likely to focus on working with green projects in the initial stages, after which a larger segment of the market may begin to develop.

Green bonds are a fixed-income instrument, the money from the issuance of which is only intended to finance projects with environmental benefits [4].

\section{RESEARCH METHODOLOGY}

The work contains the results identified in the framework of published reports and analytical materials of international organizations, specialized analytical publications, data from foreign and Russian news agencies, as well as interviews and articles of leading analysts and experts. The methods of the performed research contain theoretical and empirical parts, description methods and are supported by graphical methods of data illustration.

\section{RESEARCH RESULTS}

A resilient region is more than a territory which is successful at economic development [5].

Over the past few years, the global green finance market and especially its broadest part - the green bond segment - has been active in creating project investment methodologies (at national levels) as well as standards and requirements for the organisation of these securities issues (general guidelines for the financial market), tracking, tracking and reporting and maintaining transparency on project cash flows. By 2020, several international standards have been developed (e.g. Green Bond Principles, Climate Bonds Standard), and there are also regional standards (Association of Southeast Asian Nations, ASEAN guidelines). There are also countries that have defined their own national standards: for example, Brazil, China, India. Over the past few years, the domestic financial market has been working on a methodological and regulatory framework for the full-fledged use of green bonds in Russia. In the summer and fall of 2020 , there was a lot of activity and discussion on this topic at the ministerial and regulatory levels. Although domestic issuers with green issues appeared almost two years ago. The financial market regulator, the Bank of Russia, -introduced the concept of green bonds into its securities issuance standards in April 2020-, with the proceeds from their placement to be used for purposes related to financing and/or refinancing environmental protection projects. Holders of such securities should have the right to early redemption in case of inappropriate use of the attracted capital. At the same time, the VEB.RF is developing a national system of green finance and has already published the relevant methodology. So far, it is rather a framework document, which defines the most relevant areas for launching "green" projects, as well as the criteria for the compliance of financial instruments with the methodological recommendations with the involvement of a verifier. At the same time, the methodology does not mention the standards for issuing CB securities regulating the issue of green bonds in the domestic market, nor does it specify measurable criteria for the selection of projects aimed at improving the environment. Individual initiatives to introduce elements of green finance have arisen before. In April 2019, -a government decree was approved on the rules for allocating subsidies for issuers who issue bonds to finance the reduction of the negative impact on the environment in their projects. Moreover, such incentives for implementation of the best available technologies (BAT) have been extended even to enterprises with significant negative environmental impact (such category includes producers of coke and oil products, oil and gas production enterprises, metallurgical production and other organizations).

Companies are entitled to compensate up to $70 \%$ of the costs of coupon income paid to investors in these securities, and even up to $90 \%$ if domestic equipment was used in the project. The estimated amount of the subsidy depends on the maturity of the bond, the key rate and the value of the coupon- 
free yield curve of OFZs with a maturity of 10 years. The subsidy is not granted if the coupon rate exceeds the estimated value by $9 \mathrm{p}$. The possibility to subsidize the coupon rate for industrial enterprises is not in demand, and not a single planned ruble was spent neither in 2019 (then it was planned to compensate up to 300 million rubles), nor in the expiring 2020-. The budget allocates funds to compensate coupon payments on these bonds as follows: Rb 3bn. - in 2020 and Rb 6bn in 2021. - in 2021. In our opinion, the domestic market is still unable to synchronize the existing approaches and initiatives for the "greening" of the economy, especially in terms of understanding the "shades" of green. For example, the BAT proposal would fit into green finance, but not if such an initiative comes from a carbon-intensive company. This is more like a tool of "transitional development". (see "How is the green bond market developed?" for more details). Nevertheless, the work of the Bank of Russia, the Ministry of Economic Development together with VEB.RF and other ministries and departments, the expert and business community, as well as in cooperation with specialized organizations that have accumulated extensive experience (such as CBI and verifier SynTao Green Finance) and international development institutions on the horizon of up to one to two years, in our estimate, may lead to the publication of a well-established methodology for green finance. According to a recent government decree, the Ministry of Economic Development has been appointed as the coordinating body for developing investment activities and attracting private financing to sustainable development projects (including green projects), while the function of the methodological center has been transferred to VEB.RF.

Russia's sustainable finance market is just beginning to develop. Currently, there are 19 issues of green and social bonds of Russian issuers worth about $\$ 3$ billion, many of which are listed on the Moscow Exchange and included in the international databases of ICMA, CBI and EF43.

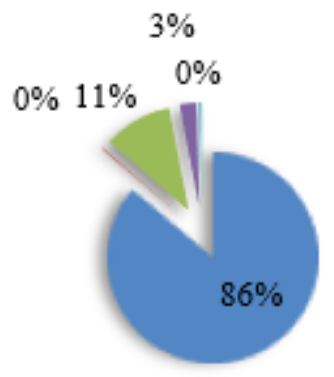

$\begin{array}{ll}\| \text { Ports } & \quad \text { Water supply } \backsim \text { Energy } \\ \square \text { Aeroports } & \square \text { Roads }\end{array}$

Figure 1 Issue of green and social bonds by Russian companies by industry 2016-2020, $\$$ billion [6]

Over the entire period, 15 green bonds were issued for a total amount of approximately $\$ 2.5$ billion. The funds from them were used to implement projects in the transport sector (Russian Railways and Transport Concession Company) and in the energy sector (KB Center-Invest and SFO RuSol 1). The Issuers have also raised funds in areas such as housing and utilities, waste management, commercial real estate and green technology.

«Khantys-Mansis Resource Saving Company» became the first issuer of green bonds in Russia. In December 2018, the company completed the placement on the Moscow Exchange of a bond issue with a total nominal value of RUB 1.1 billion. The bond issue fully complies with the Green Bond Principles 2018 and was included in the international register of green bonds Environmental Finance Bond Database. The funds from the bond placement are used to finance the concession project for the creation of an integrated intermunicipal landfill for the disposal, neutralization and treatment of solid waste for the cities of Nefteyugansk, Pyt-Yakh and settlements of the Nefteyugansk district, under which a wastesorting complex with a processing capacity of 100 thousand tons per year will be built [7].

Social bonds appeared on the Russian market of green financial instruments only in 2020. So far, two issuers have placed social bonds worth $\$ 409$ million. SFD Social Development issued corporate social bonds to refinance a PPP project in education and culture, and Russian Railways issued social Eurobonds to improve transport accessibility, medical and educational services. [8].

The green finance market in Russia is expected to grow significantly by the end of 2021 - up to RUB 
250 billion [9]. This is due to possible state support of ESG initiatives and bond coupon rate subsidies. In addition, many large banks have already introduced KPIs for ESG metrics in investment processes, and their share is projected to increase to $50 \%$ by the end of the year.

Many "green" projects can be launched in publicprivate partnership formats. For example, in the field of waste management or development of urban public transport. At the same time, a number of Russian regions have more prerequisites for their implementation: their territory has more pronounced environmental problems, and they can "afford" concession and PPP formats -due to financial stability and experience in launching such projects.

\section{RESULT DISCUSSION}

There are a lot of environmental problems in Russia, and they need to be solved by joint publicprivate efforts. However, investors in Russia are not showing high demand for green issues and are looking solely at financial performance.

It was decided to stimulate market development by providing benefits to both issuers and investors in green financial instruments. At the same time, it was decided to reduce the risks of misuse and greenwashing by unifying approaches and creating the VEB.RF methodology to verify green bonds and financial instruments.

The Ministry of Economic Development and the Central Bank also got involved in the regulation. In May 2020, the regulator supplemented Resolution 706-P of 19.12.2019 with listing rules for green and social bonds, and Moscow Exchange confirmed that it is moving to the new requirements. They are broadly based on international experience, but with some key differences.

Firstly, the listing rules now require not verification of the issuer's approach to selecting green projects, but verification of the projects themselves. Secondly, the concept of green default does not exist in the world. In Russia, issuers are forced to add a condition on the possibility for investors to demand redemption of bonds in case of misuse of funds.

As a result, in an attempt to prevent manipulation of green credentials, the country has withdrawn support for key industries and significantly tightened the rules for recognizing bonds as green by abandoning verification of approaches and switching to project verification. There are already risks of seeing a red light on the development of the green finance market. It is hoped that certain regulatory measures will be revised, in particular, there will be a return to verification of approaches, not just projects, and the condition of forced redemption in case of misuse will be replaced, for example, by worsening the terms of financing through a coupon increase.

Stock exchanges, rating agencies and other specialized organizations are developing green indices to develop investments in green-linked companies and instruments. International experience shows that the development of green equity and bond indices can direct more capital to the relevant sectors. More often than not, green equity indices cover a large number of companies that comply with responsible investing principles and are interested in transitioning to green technologies. There is a diversity of sectors and areas, or families, of indices related to green finance in the stock markets. MSCI, for example, distinguishes ESG equity indices in its lineup along several lines: aggregated by highest score, by sector, and by impact objective (sustainability, global environment) and others. In addition to the direction of ESG indices by territory, country and other parameters, S\&P has a separate section for "indexing" securities of companies that neither enter nor own assets in the fuel and energy complex. The Russian financial market has a sector of ESG indices, launched on April 1, 2019 by the Moscow Exchange together with the RSPP [10]. There, the "MosExchange Index - RSPP Responsibility and Openness" and the "MosExchange Index - RSPP Vector of Sustainable Development" are calculated on a daily basis. New bases for calculation of the indices were launched on January 27, 2020: they include listed shares whose issuers made up the leading group based on an assessment of the sustainability and corporate social responsibility reporting of major Russian companies (as calculated by RSPP). The Responsibility and Transparency Index includes shares of the leading companies in terms of the volume and quality of information disclosure (FGC UES and Tatneft), while the Sustainable Development Vector Index includes leaders in terms of performance and focus (shares of FGC UES, NOVATEK, PhosAgro, Polyus, Rosseti, Tatneft, TMK and RUSAL).

\section{CONCLUSION}

Thus, Russia already has the first tools to operate and expand the green finance sector and attract investors' funds through this instrument. But due to the -lack of a sufficiently wide practice of green bonds issuance and the weak regulatory framework so far, there is no index of bonds of this type. We expect that on the five-year horizon, new indices, 
including a green bond index, could be launched in the domestic market, especially if the sustainability sector on the Moscow Exchange becomes more populated.

The country is already implementing projects in the field of RES, green transport and municipal solid waste, integrating sustainability aspects into national development goals until 2030, and developing a green finance market, including a growing number of green and social bond issues. In addition, sustainability assessment initiatives for infrastructure projects are being launched, taking into account best international SD practices. All this creates conditions for further consideration of sustainable development principles and infrastructure focused on positive economic effects in the long term, as well as meeting social and environmental challenges in the 21 st century.

\section{REFERENCES}

[1] A.Dynkin, E. Telegina, World Economy and International Relations, 64(8) (2020) pp. 5-16. DOI: https://doi.org/10.20542/0131-2227-2020-648-5-16.

[2] How coronavirus affects the achievement of sustainable Development goals: aggravation of problems and "green" plans for the future, https://ach.gov.ru/news/kak-koronavirus-vliyaetna-dostizhenie-tseley-ustoych ivogo-razvitiyausugublenie-problem-i-zelenye-p.

[3] Rusnano and Rostec structure jointly organized the "First Environmental Fund". https://expbiz.ru/economics/rosnano-i-strukturarostekha-sovmestno-organizovali-pervyjekologicheskij-fond.html

[4] Green Bond. https://nesrakonk.ru/green-bond/

[5] 10M. Szabo, M.S. Csete, T. Palvolgyi, European Journal of Sustainable Development, 7(1) (2018) pp. 395-411. DOI: https://doi.org/10.14207/ejsd.2018.v7n1p395.

[6] Developed by the National PPP Centre based on Infragreen data

[7] LLC "KhMAO Resource Saving" became the first issuer of "green" bonds in the country. https://fondugra.ru/news/10497/

[8] Russian green finance market to double in a year // Rossiyskaya Gazeta

[9] Russian green finance market to double in a year, Rossiyskaya Gazeta
[10] Association of Russian Banks. https://www2.deloitte.com/content/dam/Deloitte/ru /Documents/research-center/esg-banking-russia.pdf 